\title{
The Pledge as a Legal Instrument for Reinforcement of the Contract
}

\author{
Skender Gojani, PhD \\ Lecturer, Faculty of Law, University of Prizren "Ukshin Hoti", Kosovo \\ skenda@gmail.com
}

\section{Doi:10.5901/mjss.2015.v6n2s2p197}

\begin{abstract}
The contract is made with the aim of achieving harmonized interests of contractors. Contractors, such as the seller and the buyer, initially align goals and mutual interests and, as such, they set in the contract, in order to realize in practice. This is the normal course of contracting and contractual implementation. However, in practice, it often happens that, at least one contractor to disobey them adequately its contractual obligation and, to the extent and in what form, to damage the contractor. After that, the judicial proceedings for the realization of contractual requirement of contractor damaged, to the extent of consideration, is complex and lengthy, in that proceeding, the damaged contractor, again, is disadvantage. Consequently, in practice, are applied forms of respective insurance forms of contractual of request of contractual creditor. Such a practice is called "instrument for reinforcement the contract". Instrument for reinforcement of the contract, is regulated with a clausal of contract and presents its accessory element. When the contract is perfected in accordance with contractual terms, contractual enforcement instrument, is not activated and vice versa. In theory and in practice, are recognized and applied multiple instruments, and different to enforce the contracts, among which, worth to be emphasized the Pledge.
\end{abstract}

Keywords: the pledger, pledgee, Contractor, liability, insurance

\section{Introduction}

Pledge (in movable goods "res mobiles", while, on real estate "immobile res" - imobiles" -pledge) is practiced as suitable instrument for securing the contract. The good "res" loaded with pledge, should be available on the market but can be ideal part of it. Also, instead of the good, can also be pledge a property right which is appropriate for the creditor in order to achieve the contractual requirement to provide it. The contractual right of pledge is a real type of insurance liabilities, unlike bail, which also is one of the instruments of insurance liabilities, but of personal character. So bail, is a personal instrument of liability insurance, while, pledge, is a real instrument in the same function.

However, the movable property pledge "pignus" or on real estate "mortgage" is the safest instrument for reinforcement of the contract of bail, which relies on personal components, moral and values assigned to bail, which, as such, in practice, cannot monetized as practicable to the thing charged with pledge.

\subsection{The right of pledge}

The right of pledge is a real right, with what its holder is not authorized to use the pledge, but only to dispose for contractual fulfilment of contractual demand unfulfilled from his debtor and, when is found that the debtor has failed in fulfilling the certain contractual obligation.

With pledge contract, the debtor, as the pledge debtor is obliged to, he or another person, as pledger, to give any movable good to pledge creditor, in which there is a right of property, so that he before other creditors can collect from its value, if the request will not be paid before expiry, whereas, the pledge creditor, owed that, the taken thing to save and maintain and after its request, to return to the pledger.

\subsection{The right of pledge profit}

For acquisition of the right of pledge, the pledge contract is a legal base "titulus". Except titulus for pledge contract is required the ways of getting the pledge "modus acquirendi", which is realized at the time of receipt of the pledge.

Essentially, the contract for the pledge, even though resembles the real contract, is consensual and oneroze contract. In contract for pledge is established the legal report for the pledge between the creditor and debtor of the pledge. Usually, the pledger is the entity that has the right to request from legal-binding relationship. When a bank lends 
(loan) to borrower $€ 100,000$ and he pledges the property with a value of $€ 167,000$, in the contraction, the bank is lender and pledgee, while the borrower is the borrower and the pledger.

The pledger can be the borrower but also the entity (from the Roman law; POMPIUS: "PLUS CAUTIONIS IN RE EST QUAM IN PERSONA") who does not get borrowings from the lender but guarantee the borrower with the thing that use as pledge.

Such contracting is of multilateral type. The object of the pledge can be each movable or real estate good which is in circulation "res in commercial".

Also, the items in the joint, for the adequate part of the owner, can be charged with pledge. The object of pledge must be specified and defined.

Gams- considered the item left as pledge must be individualized. Pledger obtains the right in pledge when he gets the thing left as pledge. Such pledge is possessory pledge.

Pledge can be standard when the pledged object remains in the possession of the pledger. However, possessory pledge, the pledge holder is handy, because, in case of failure of the debtor's contractual pledge, the pledge can be accomplished more easily and quickly.

For valid contracting for pledge is requires that the pledger to have ingenuity of handling the pledged item. Only thing that is owned by the pledger may be left as pledge, as authorized owner to legally accessed with the "lus Utendi" lus Fruendi "lus Abutendi".

By law and in practice tolerated and applied successor or pledges or pledge in pledge known as under pledge. The contract for pledge can be done to advance the thing pledged.

The pledge can be put in next duty and obligation liability, as can be conditional pledges and credit pledge with certain commercial paper. The right of pledge is also in the secondary requirements associated with the primary requirement, such as the interest, costs pledgee holder for holding securities and expenses for the realization of the pledge. The reports and legal affairs secured by pledge business, is not allowed:

- Transfer of pledge into the property of the pledgee after the contractual failure of the pledge debtor, neither

- Selling the pledge from the pledgee with a price established previously by him with the pledger.

However, is permitted that the pledgee, in legal proceedings, to sell the pledge with a price that the pledge item has as a standard and for that price he can take itself.

The pledger is obliged to submit the pledgee or a third person designated by them, the thing (res) which is the object of the contract or document which entitles the holder the exclusive right of availability with it.

\section{Pledger and the Pledgee}

Contractors, pledger and pledgee, may agree that the thing pledged, to keep together. In all cases, the pledger or other person is authorized to maintain the pledged item (the possessory pledge) is required to save the object with good care economies. When the debt is back, the owner of the thing pledged, authorized for its retention must return the object to the same condition and form as contracted.

Also, the pledgee who use pledge without the authorization of the pledger, is responsible for damage or destruction caused pledge odd in that case.

When the pledge gives fruits, (Antichresis), while, between contractors is not defined their case, they, in principle belong to the pledger. Similarly applies to benefit from the thing pledged. If pledge collateral has factual or legal defect, the pledgee is entitled to request from the pledger to replace such collateral.

In case the debtor, with time or under contract does not fulfil the contractual obligation, the creditor has the right to ask the court of jurisdiction to sell the pledge collateral in auction, and, if the pledged collateral has a stock price or market price, to sell it with current prices. Pledgee, has the right that from the realized price from the sale of collateral to pledge, to collect money before the other creditors:

- Contractual requirement (Pledge can be: legal pledge, when assigned to law enforcement; judicial pledge, which is determined on court proceeding or contractor pledge, which is stipulated from the relative contractors)

- The relevant interest rate;

- Costs incurred for the maintenance and preservation of the pledge (possessory pledge);

- Expenses for collection of contractual demand.

Negative pledge applies when the pledger, in the pledge agreement commits that pledge collateral will not impose to another pledge. Collateral is property or movable property which can be transferred legally. Joint property may be collateral on the consent of the co-owners. A person who has partial interest in movable property, that interest can leave 
as collateral. With pledge collateral can be ensured the total amount of the obligation secured with the pledge. With pledge can be secured some liabilities. To be a valid pledge requires that the secured obligation may be expressed monetary.

Pledge can be:

- Standard;

- Possessory and

- Cash buyer.

- Pledge can be manifested as:

- Pledge in bank account;

- Pledge in cash or

- Pledge in contractual obligation and in any movable goods.

For perfection of pledge, among other things, is required the statement of pledge (The Notification Statement), which should be recorded (must be filed). Declaration of pledge a minimum should contain:

(Pledge means an intentionally created interests in movable property that gives the pledge holder the right to take possesion of such property for the purpose of satisfying or attempting to satysfy a secured obligation in accordance with the application law):

- Sufficient identification of the pledger;

- General or specific identification of the secured obligation;

- The maximum amount of the secured debt expressed in money;

- Identification of the collateral;

- Signature of the pledger or his authorized person and

- The date when the pledge was given and its registration.

According to the Law on Pledges, pledge terminate (ends) when:

- $\quad$ The pledger and pledgee agree;

- The obligation secured is calculated;

- The collateral finish existing;

- Collateral is changed or incorporated with any item or other right;

- The collateral becomes part of the property or other right;

- Collateral becomes property of the pledgee (the collateral becomes owned by the pledge holder).

When the debtor fails to fulfil the obligation secured by the pledge, the pledgee as creditor, if it did not have in possession the collateral (possessory pledge), pledge collateral can take in the possession through:

- Court (proceedings) action (Judicial action);

- Its action with the condition not to break law and order or

- Administrative proceeding.

In court proceedings, the pledger, may make application to the court of jurisdiction to give the order "ex parte" with which, to allow the taking of collateral in its possession as a creditor (plaintiff).

The court, in unusual circumstances, decides for the issue within three days of conform to the application of the pledgee. In three other days, the pledger or the person authorized and legal legitimate active (legal interest), may exert contrary to the court's decision for allowing dismission of pledge and the court, also, within the same time must decide by opposition.

The decision by the opposition and decision against whose within three days is not exercised the objection, becomes final, so that, pledgee, may proceed with the execution of the pledge.

When the pledge is a possessory, judicial processing is shorter, so that the pledgee, from the court of jurisdiction requires ex parte to allow the sale of collateral of pledge.

In the case of not fulfilling the contractual liability of the debtor (pledger), the creditor (pledgee), can sell the pledge, to hire or dispose of, and the incomes of such pledge collateral, should dispose for:

- Reasonable expenses for taking in possession, putting on sale and realization of sale of collateral of pledge;

- Fulfilment of the obligation secured;

- Fulfilling the obligations to the subsequent pledgee on the same collateral and

- The rest part (if there is any left part) is returned to the pledger.

Except on the case when is contracted differently, the pledger remains liable to the pledgee for the debt which cannot be covered by the sale of pledge collateral. 
Alienation of the pledged collateral, compliance with contracts and local shopping habits, can be realized:

- At public auction or in

- Private sale (if the pledge holder proceeds by Judicial action scarf times file an application with the Court with appropriate jurisdiction requesting on order ex parte and without notice to the pledger or any other person authorizing the collateral to be seized and delivered to the Pledge holder pursuant to Judicial process). However, the pledgee, before, must inform the pledger and other pledgees in the same collateral, for the day and place of sale of pledge collateral. Pledgee, in principle, cannot buy the pledge collateral except when:

- Pledge collateral is sold on a recognized market or

- For collateral exist standard prices widely known.

Also, the pledgee can offer the pledge collateral for fully or partly fulfilling of the ensured demand, if:

- $\quad$ The pledger is agreed and

- Debtor including each other debtors, within 14 days of receipt of the offer, stating no objection. The pledge, must first register and when the obligation guaranteed is fulfilled, without delay, the same should be deregistered. Registration and deregistration of the pledge is made at the designated office for that official work.

\section{Conclusion}

We managed to understand that contract is a very important contributor instrument and liability under mandatory law and also provides a central institution within the legal communications between the contracting parties.

In legal theory, the contract is defined as will consent between two or more parties to which they come for the purpose of ascertaining, change or break the relation of any legal liability. So, contracting is done with the aim of achieving harmonized interests of contractors. Contractors, such as the seller and the buyer, initially align goals and mutual interests and, as such, is set in the contract, in order to realize in practice. With pledge contract, the debtor, as the pledge debtor is obliged to, he or another, as pledger, to give any movable good to the pledge creditor, in which there is a right of property, so that he before other creditors can collect from its value, if the request will not be paid before expiry, whereas, the pledge creditor, owed that, the thing that he takes, to maintain the item taken and return it to the pledger.

\section{References}

Smaka Dr.Sc. Riza., Gojani Mr. Sc. Skender., The Business Law, Prishtina 2012

Dauti, Dr.Sc. Nerxhivane, The Liability Law, Prishtine,2004,

Gorenc, Viliam, Fundamentals of the Business Law Statutory and Contractual, Prishtina 2010,

Dauti, Dr. Nerxhivane, Mandatory Law, UP - Juridical Faculty, Prishtina 2003

Gams, Andrija, Introduction to the Civil Law , Prishtina, 1981

Krasniqi, dr, Armand, Universitety of Prishtina, the School of Business, Pejë 2012

Gojani, Skender, Glossary Legal Terminology, Prishtina 2013

Semini (Tutulani), Dr. Mariana, The Contractual and mandatory law, General Overview, Tirana, 2002.

Krasniqi, Armand, The Business Right, Dukagjini, Peje 2014

Law No. 03/L-154 " on Property and other Real Rights" Prishtina, 25,06, 2009

Law No. 04/L-077 "on Obligational Relationships" 10 May 2012 